Article

\title{
Preparation of Enantiomerically Enriched $P$-Stereogenic Dialkyl-Arylphosphine Oxides via Coordination Mediated Optical Resolution
}

\author{
Bence Varga and Péter Bagi *(i) \\ Department of Organic Chemistry and Technology, Budapest University of Technology and Economics, \\ Múegyetem rkp. 3., H-1111 Budapest, Hungary; varga.bence@mail.bme.hu \\ * Correspondence: pbagi@mail.bme.hu
}

Received: 12 December 2019; Accepted: 14 January 2020; Published: 2 February 2020

\begin{abstract}
Optical resolution of several dialkyl-arylphosphine oxides was elaborated using the $\mathrm{Ca}^{2+}$ salt of (-)-O,O'-dibenzoyl-( $\left.2 R, 3 R\right)$-tartaric acid as the resolving agent. The conditions of crystallization and purification of the enantiomerically enriched phosphine oxides were optimized. Ethyl-phenyl-propylphosphine oxide and butyl-methyl-phenylphosphine oxide were prepared with an enantiomeric excess higher than $93 \%$, whereas, three other dialkyl-arylphosphine oxides were obtained with an enantiomeric excess of $37-85 \%$. It was also found that the sterically demanding alkyl chains hinder the formation of stable diastereomeric complexes, which consequently led to less efficient resolution procedures.
\end{abstract}

Keywords: dialkyl-arylphosphine oxide; $P$-stereogenic; optical resolution; enantiomeric separation

\section{Introduction}

Chiral compounds form an important class in organophosphorus chemistry. These species may contain an asymmetric element either on the phosphorus atom or at other parts of the molecular scaffold [1-3]. Chiral organophosphourus compounds were traditionally used as ligands in transition metal-catalyzed transformations [4,5]. In the past two decades, application of phosphines [6-8], phosphine oxides $[9,10]$ or phosphonium salts $[11,12]$ as enantioselective organocatalysts became an emerging area. Many enantioselective (organo)catalytic transformations take place in the close proximity of the phosphorus atom, which signifies the application of the corresponding $P$-stereogenic species [13].

Methods developed for the preparation of $P$-chiral compounds include stereoselective syntheses from racemic or prochiral starting materials using chiral catalysts [14,15] or auxiliaries [16-24], stereospecific transformations of secondary phosphine oxides or phosphinates [16,25-28], as well as kinetic [29-33], dynamic kinetic [34-38], chromatographic [39,40] or classical resolutions [41-46]. Classical resolutions are generally robust, bench-stable processes that can be scaled up. Moreover, resolving agents can be recycled, and the undesired enantiomer can be racemized and reused [47,48]. One group of resolution methods developed for chiral phosphine oxides applies classical resolving agents having either acidic or basic character. However, this strategy requires the presence of basic or acidic functional groups in the racemic $P$-derivative [49]. Other resolution strategies rely on interactions between the $\mathrm{P}=\mathrm{O}$ group of a phosphine oxide and the $\mathrm{H}$-bond donor functional groups of the resolving agent. BINOL [41], TADDOL- [44,45], camphorsulfonic acid- [50], mandelic acid- [42] or tartaric acid derivatives $[37,43]$ were used for the optical resolution of $P$-stereogenic phosphine oxides. BINOL and TADDOL-derivatives are relatively expensive, whereas optical resolutions with chiral acids had a rather limited scope. Another resolution method may involve a combination of the enantiomeric recognition 
ability of a chiral resolving agent, and the coordination ability of a metal ion. In this manner, good enantiomeric separation could be achieved, even with cheap resolving agents. This coordination mediated resolution technique was used to separate the enantiomers of chiral alcohols, hydroxy- or halo carboxylic acids [51-55]. Moreover, $\mathrm{Ca}^{2+}$ - and $\mathrm{Mg}^{2+}$-salts of tartaric acid derivatives were suitable resolving agents for the preparation of several five- and six-membered $P$-heterocycles in optically active form [44], and our research group published one example for the enantiomeric separation, an acyclic diaryl-alkylphoshophine oxide [45]. Antipodes Tenofovir Alafenamide could also be separated using a coordination mediated resolution. It indicates that resolution procedures have high value for biologically active organophosphorus compounds, as well [56].

In this paper, the optical resolution of a series of dialkyl-phenylphosphine oxides was studied. For this compound class, only one resolution method applying BINOL was reported. Thus, our aim was to investigate, whether the significantly cheaper metal salts of tartaric acid derivatives can be used for the optical resolution of the selected acyclic phosphine oxides, as seen in Figure 1.
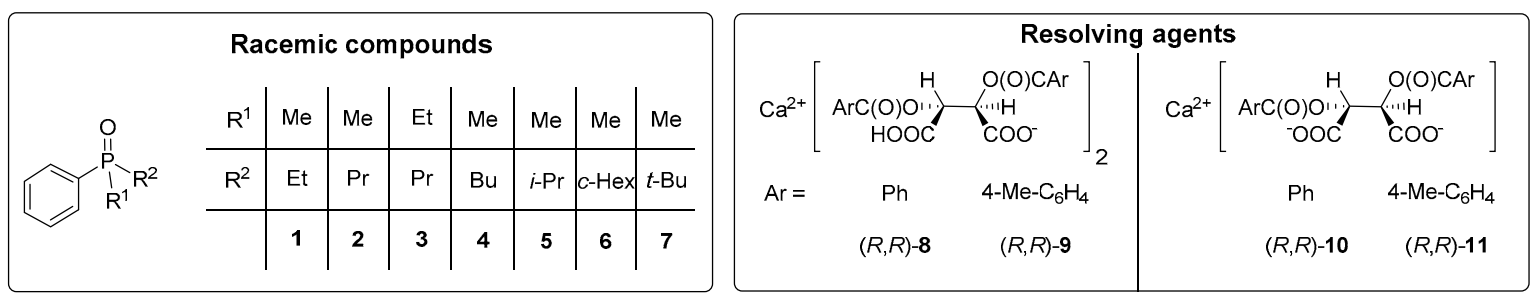

Figure 1. Racemic dialkyl-arylphosphine oxides (1-7) and resolving agents $[(R, R)-\mathbf{8}-[(R, R)-\mathbf{1 1}]$ used in this study.

\section{Materials and Methods}

\subsection{General}

The details of chemicals, instruments used in this study, a few synthetic procedures, as well as the characterization of optically active P-oxides (1-7) can be found in the Supplementary Material.

\subsection{Resolution of Ethyl-Phenyl-Propylphosphine Oxide (3) with in Situ Prepared Resolving Agents (Representative Procedure)}

In total, $0.096 \mathrm{~g}(0.26 \mathrm{mmol})$ of DBTA. $\mathrm{H}_{2} \mathrm{O}$ and $7.1 \mathrm{mg}(0.13 \mathrm{mmol})$ of $\mathrm{CaO}$ were refluxed in $0.31 \mathrm{~mL}$ of ethanol and $31 \mu \mathrm{L}$ of water until it became clear. To this solution of in situ formed Ca(H-DBTA $)_{2}$ [(R,R)-8], $0.050 \mathrm{~g}(0.26 \mathrm{mmol})$ of racemic ethyl-phenyl-propylphosphine oxide (3) in $0.31 \mathrm{~mL}$ of hot ethyl acetate was added. Colorless crystalline diastereomeric complex of $(S)-3 \cdot \mathrm{Ca}(\mathrm{H}-\mathrm{DBTA})_{2}$ appeared after cooling the mixture to $25^{\circ} \mathrm{C}$. After standing at $25^{\circ} \mathrm{C}$ for $24 \mathrm{~h}$, the crystals were separated by filtration, washed with a mixture of $0.10 \mathrm{~mL}$ of ethanol and $0.10 \mathrm{~mL}$ of ethyl acetate, to give $0.075 \mathrm{~g}$ $(62 \%)$ of $(S)-3 \cdot \mathrm{Ca}(\mathrm{H}-\mathrm{DBTA})_{2}$ with a de of $69 \%$ (Table 1, Entry 2$)$.

Resolution of racemic phosphine oxides (1-7) was performed according to this representative procedure when the following resolving agents were used: $\mathrm{Ca}(\mathrm{H}-\mathrm{DBTA})_{2}[(R, R)-8], \mathrm{Ca}(\mathrm{H}-\mathrm{DPTTA})_{2}$ $[(R, R)-9], \mathrm{Ca}(\mathrm{DBTA})[(R, R)-10]$ and $\mathrm{Ca}(\mathrm{DPTTA})[(R, R)-11]$. Conditions and results are shown in Table 1 , Entries 3-5, and in Table 2.

When $\mathrm{Ca}(\mathrm{DBTA})[(R, R)-10]$ or $\mathrm{Ca}(\mathrm{DPTTA})[(R, R)-11]$ was the resolving agent, the molar ratio of DBTA $\cdot \mathrm{H}_{2} \mathrm{O}$ or DPTTA $\mathrm{H}_{2} \mathrm{O}$ and $\mathrm{CaO}$ was 1:1 (Table 1, Entries 3 and 5). When resolutions were carried out according to the equivalent method, the amount of DBTA $\cdot \mathrm{H}_{2} \mathrm{O}$ and $\mathrm{CaO}$ was doubled (Table 2, Entries 10-16).

When different solvent mixtures were used for resolution, the resolving agent $[(R, R)-8]$ was prepared in situ in the corresponding alcohol and water, and phosphine oxide 3 was added in the other component of the solvent mixture. When only ethyl acetate was the solvent, diastereomeric complex (S)-3.Ca(H-DBTA $)_{2}$ was prepared, as described above. Then the solvent was evaporated 
under reduced pressure, and diastereomer $(S)-3 \cdot \mathrm{Ca}(\mathrm{H}-\mathrm{DBTA})_{2}$ was re-dissolved in boiling ethyl acetate. Crystallization and isolation of the diastereomer were carried out according to the representative procedure described above (Table 2, Entry 9).

Table 1. Optical resolution of ethyl-phenyl-propylphosphine oxide (3) with different $\mathrm{Ca}^{2+}$ salts of tartaric-acid derivatives $[(R, R)-8-(R, R)-\mathbf{1 1}]$.

\begin{tabular}{|c|c|c|c|c|c|c|c|c|}
\hline Entry & $\begin{array}{l}\text { Resolving } \\
\text { Agent }\end{array}$ & Eq. & Solvents ${ }^{a}$ & $\begin{array}{c}\text { Diastereomeric } \\
\text { Complex }\end{array}$ & $\begin{array}{l}\text { Yield c,g } \\
(\%)\end{array}$ & $\begin{array}{c}E e^{\mathrm{d}, \mathrm{g}} \\
(\%)\end{array}$ & $\begin{array}{c}S^{e, g} \\
(-)\end{array}$ & $\begin{array}{l}\text { Abs. } \\
\text { Config. }\end{array}$ \\
\hline $1^{\mathrm{h}}$ & $\mathrm{Ca}(\mathrm{H}-\mathrm{DBTA})_{2}$ & 0.5 & $3 \times \mathrm{EtOAc} / 3 \times \mathrm{EtOH}$ & (3) $\cdot \mathrm{Ca}(\mathrm{H}-\mathrm{DBTA})_{2}$ & 83 & 44 & 0.36 & $(S)$ \\
\hline $2^{i}$ & $\mathrm{Ca}(\mathrm{H}-\mathrm{DBTA})_{2}$ & 0.5 & $3 \times \mathrm{EtOAc} / 3 \times \mathrm{EtOH} / 0.3 \times \mathrm{H}_{2} \mathrm{O}$ & (3) $\cdot \mathrm{Ca}(\mathrm{H}-\mathrm{DBTA})_{2}$ & 62 & 69 & 0.43 & $(S)$ \\
\hline $4^{\mathrm{i}}$ & $\mathrm{Ca}(\mathrm{H}-\mathrm{DPTTA})_{2}$ & 0.5 & $3 \times \mathrm{EtOAc} / 3 \times \mathrm{EtOH} / 0.3 \times \mathrm{H}_{2} \mathrm{O}$ & (3) $\cdot \mathrm{Ca}(\mathrm{H}-\mathrm{DPTTA})_{2}$ & 66 & 38 & 0.25 & $(S)$ \\
\hline $5^{\mathrm{i}}$ & $\mathrm{Ca}(\mathrm{DPTTA})$ & 0.5 & $3 \times \mathrm{EtOAc} / 3 \times \mathrm{EtOH} / 0.3 \times \mathrm{H}_{2} \mathrm{O}$ & no complex & - & - & - & - \\
\hline
\end{tabular}

Table 2. Optimization of crystallization conditions for the resolution of ethyl-phenyl-propylphosphine oxide (3) with $\mathrm{Ca}(\mathrm{H}-\mathrm{DBTA})_{2}[(R, R)-8]$ prepared in situ.

\begin{tabular}{|c|c|c|c|c|c|c|c|}
\hline Entry & $\begin{array}{c}\text { Eq. of } \\
\mathrm{Ca}(\mathrm{H}-\mathrm{DBTA})_{2}\end{array}$ & Solvents ${ }^{\text {a }}$ & $\begin{array}{l}\text { Diastereomeric } \\
\text { Complex }\end{array}$ & $\begin{array}{l}\text { Yield c,g } \\
(\%)\end{array}$ & $\begin{array}{c}E e^{\mathrm{d}, \mathrm{g}} \\
(\%)\end{array}$ & $\underset{\mathrm{e}, \mathrm{g}_{(-)}}{S}$ & $\begin{array}{l}\text { Abs. } \\
\text { Config. } f\end{array}$ \\
\hline $1^{\mathrm{h}}$ & 0.5 & $3 \times \mathrm{EtOAc} / 3 \times \mathrm{EtOH} / 0.3 \times \mathrm{H}_{2} \mathrm{O}$ & (3) $\cdot \mathrm{Ca}(\mathrm{H}-\mathrm{DBTA})_{2}$ & 62 & 69 & 0.43 & $(S)$ \\
\hline 2 & 0.5 & $3 \times \mathrm{EtOAc} / 3 \times \mathrm{MeOH} / 0.3 \times \mathrm{H}_{2} \mathrm{O}$ & (3) $\mathrm{Ca}(\mathrm{H}-\mathrm{DBTA})_{2}$ & 18 & 79 & 0.14 & $(S)$ \\
\hline 3 & 0.5 & $3 \times \mathrm{EtOAc} / 3 \times 2-\mathrm{PrOH} / 0.3 \times \mathrm{H}_{2} \mathrm{O}$ & (3) $\cdot \mathrm{Ca}(\mathrm{H}-\mathrm{DBTA})_{2}$ & 66 & 17 & 0.11 & $(S)$ \\
\hline 4 & 0.5 & $3 \times \mathrm{BuOAc} / 3 \times \mathrm{EtOH} / 0.3 \times \mathrm{H}_{2} \mathrm{O}$ & (3) $\mathrm{Ca}(\mathrm{H}-\mathrm{DBTA})_{2}$ & 70 & 55 & 0.38 & $(S)$ \\
\hline 5 & 0.5 & $3 \times$ acetone $/ 3 \times \mathrm{EtOH} / 0.3 \times \mathrm{H}_{2} \mathrm{O}$ & (3) $\mathrm{Ca}(\mathrm{H}-\mathrm{DBTA})_{2}$ & 62 & 14 & 0.08 & $(S)$ \\
\hline 6 & 0.5 & $3 \times \mathrm{MeCN} / 3 \times \mathrm{EtOH} / 0.3 \times \mathrm{H}_{2} \mathrm{O}$ & (3) $\mathrm{Ca}(\mathrm{H}-\mathrm{DBTA})_{2}$ & 42 & 18 & 0.06 & $(S)$ \\
\hline 7 & 0.5 & $3 \times$ toluene $/ 3 \times \mathrm{EtOH} / 0.3 \times \mathrm{H}_{2} \mathrm{O}$ & (3) $\cdot \mathrm{Ca}(\mathrm{H}-\mathrm{DBTA})_{2}$ & 27 & 0 & 0.00 & $(S)$ \\
\hline 8 & 0.5 & $6 \times \mathrm{EtOH} / 0.3 \times \mathrm{H}_{2} \mathrm{O}$ & $(3)_{4} \cdot \mathrm{Ca}_{3}(\mathrm{H}-\mathrm{DBTA})_{6}$ & 75 & 44 & 0.33 & $(S)$ \\
\hline 9 & 0.5 & $6 \times$ EtOAc & $(3)_{2} \cdot \mathrm{Ca}(\mathrm{H}-\mathrm{DBTA})_{2}$ & 123 & 12 & 0.15 & $(S)$ \\
\hline 10 & 1 & $3 \times \mathrm{EtOAc} / 3 \times \mathrm{EtOH} / 0.3 \times \mathrm{H}_{2} \mathrm{O}$ & (3) $\cdot \mathrm{Ca}(\mathrm{H}-\mathrm{DBTA})_{2}$ & 79 & 74 & 0.58 & $(S)$ \\
\hline 11 & 1 & $1.5 \times \mathrm{EtOAc} / 1.5 \times \mathrm{EtOH} / 0.15 \times \mathrm{H}_{2} \mathrm{O}$ & (3) $\cdot \mathrm{Ca}(\mathrm{H}-\mathrm{DBTA})_{2}$ & 105 & 54 & 0.57 & $(S)$ \\
\hline 12 & 1 & $4.5 \times \mathrm{EtOAc} / 4.5 \times \mathrm{EtOH} / 0.45 \times \mathrm{H}_{2} \mathrm{O}$ & (3) $\cdot \mathrm{Ca}(\mathrm{H}-\mathrm{DBTA})_{2}$ & 65 & 73 & 0.48 & $(S)$ \\
\hline 13 & 1 & $5 \times \mathrm{EtOAc} / 1 \times \mathrm{EtOH} / 0.3 \times \mathrm{H}_{2} \mathrm{O}$ & (3) $\cdot \mathrm{Ca}(\mathrm{H}-\mathrm{DBTA})_{2}$ & 132 & 39 & 0.50 & $(S)$ \\
\hline 14 & 1 & $1 \times \mathrm{EtOAc} / 5 \times \mathrm{EtOH} / 0.3 \times \mathrm{H}_{2} \mathrm{O}$ & (3) $\cdot \mathrm{Ca}(\mathrm{H}-\mathrm{DBTA})_{2}$ & 57 & 71 & 0.41 & $(S)$ \\
\hline 15 & 1 & $3 \times \mathrm{EtOAc} / 3 \times \mathrm{EtOH} / 0.15 \times \mathrm{H}_{2} \mathrm{O}$ & (3) $\cdot \mathrm{Ca}(\mathrm{H}-\mathrm{DBTA})_{2}$ & 97 & 56 & 0.54 & $(S)$ \\
\hline 16 & 1 & $3 \times \mathrm{EtOAc} / 3 \times \mathrm{EtOH} / 0.6 \times \mathrm{H}_{2} \mathrm{O}$ & $\mathrm{Ca}(\mathrm{H}-\mathrm{DBTA})_{2}$ & - & - & - & - \\
\hline
\end{tabular}

\subsection{Purification of Diastereomeric Complex of (S)-3.Ca(H-DBTA $)_{2}$}

In total, $0.30 \mathrm{~g}(0.32 \mathrm{mmol})$ of $(S)-3 \cdot \mathrm{Ca}(\mathrm{H}-\mathrm{DBTA})_{2}$ with a de of $74 \%$ [prepared from $0.16 \mathrm{~g}(0.80 \mathrm{mmol})$ of racemic ethyl-phenyl-propylphosphine oxide (3), $0.61 \mathrm{~g}(1.61 \mathrm{mmol})$ of DBTA. $\mathrm{H}_{2} \mathrm{O}$ and $0.045 \mathrm{~g}$ $(0.80 \mathrm{mmol})$ of $\mathrm{CaO}$ in $1.95 \mathrm{~mL}$ of ethanol, $0.20 \mathrm{~mL}$ of water and $1.95 \mathrm{~mL}$ of ethyl acetate according to Representative Procedure (Table 2, Entry 10)] was divided into 3 equal parts.

\subsubsection{Purification of Diastereomeric Complex of $(S)-3 \cdot \mathrm{Ca}(\mathrm{H}-\mathrm{DBTA})_{2}$ by Digestion (Purification Method I)}

$0.10 \mathrm{~g}(0.11 \mathrm{mmol})$ of $(S)-3 \cdot \mathrm{Ca}(\mathrm{H}-\mathrm{DBTA})_{2}$ with a de of $74 \%$ was stirred in a mixture of $0.65 \mathrm{~mL}$ of ethanol and $0.65 \mathrm{~mL}$ of ethyl acetate at $25^{\circ} \mathrm{C}$ for $24 \mathrm{~h}$. The crystals were then separated by filtration, washed with $0.22 \mathrm{~mL}$ of ethanol and $0.22 \mathrm{~mL}$ of ethyl acetate, to give $0.061 \mathrm{~g}(47 \%)$ of $(S)-3 \cdot \mathrm{Ca}(\mathrm{H}-\mathrm{DBTA})_{2}$ with a de of $77 \%$ (Scheme $3 / \mathrm{II})$. 
2.3.2. Purification of Diastereomeric Complex of (S)-3·Ca(H-DBTA $)_{2}$ by Recrystallization (Purification Method II)

$0.10 \mathrm{~g}(0.11 \mathrm{mmol})$ of $(\mathrm{S})-3 \cdot \mathrm{Ca}(\mathrm{H}-\mathrm{DBTA})_{2}$ with a de of $74 \%$ refluxed for $5 \mathrm{~min}$ in a mixture of $0.65 \mathrm{~mL}$ of ethanol and $0.65 \mathrm{~mL}$ of ethyl acetate. Colorless crystalline diastereomeric complex of $(\mathrm{S})-3 \cdot \mathrm{Ca}(\mathrm{H}-\mathrm{DBTA})_{2}$ appeared after cooling the mixture to $25^{\circ} \mathrm{C}$. After standing at $25^{\circ} \mathrm{C}$ for $24 \mathrm{~h}$, the crystals were separated by filtration, washed with $0.22 \mathrm{~mL}$ of ethanol and $0.22 \mathrm{~mL}$ of ethyl acetate, to give $0.056 \mathrm{~g}(43 \%)$ of (S)-3.Ca(H-DBTA $)_{2}$ with a de of $94 \%$ (Scheme $\left.3 / \mathrm{III}\right)$.

2.3.3. Purification of Diastereomeric Complex of (S)-3·Ca(H-DBTA $)_{2}$ by Repeated Resolution (Purification Method III)

$0.10 \mathrm{~g}(0.11 \mathrm{mmol})$ of $(S)-3 \cdot \mathrm{Ca}(\mathrm{H}-\mathrm{DBTA})_{2}$ with a de of $74 \%$ was decomposed by extraction using $10 \%$ aqueous ammonia $(2 \mathrm{~mL})$ and extracted with dichloromethane $(3 \times 2 \mathrm{~mL})$. The organic layers were combined, dried $\left(\mathrm{Na}_{2} \mathrm{SO}_{4}\right)$ and evaporated. The $0.020 \mathrm{~g}(0.10 \mathrm{mmol}, 76 \%)$ of (S)-ethyl-phenyl-propyphosphine oxide $[(S)-3]$ with an $e e$ of $74 \%$ was resolved with $0.077 \mathrm{~g}(0.20 \mathrm{mmol})$ of DBTA $\cdot \mathrm{H}_{2} \mathrm{O}$ and $5.7 \mathrm{mg}(0.10 \mathrm{mmol})$ of $\mathrm{CaO}$ according to Representative Procedure, to give $0.062 \mathrm{~g}(48 \%)$ of $(\mathrm{S})-3 \cdot \mathrm{Ca}(\mathrm{H}-\mathrm{DBTA})_{2}$ with a de of $93 \%$ (Scheme 3/IV and V).

\subsection{Resolution of Dialkyl-Arylphosphine Oxides (1, 2, 4-7) with Ca(H-DBTA)2 [(R,R)-8]}

In total, $0.75 \mathrm{mmol}$ of phosphine oxide 1, 2 and 4-7 (1: $0.13 \mathrm{~g}, 2: 0.14 \mathrm{~g}, 4: 0.15 \mathrm{~g}, 5: 0.14 \mathrm{~g}, \mathbf{6 :}$ $0.17 \mathrm{~g}$ and $7: 0.15 \mathrm{~g})$ was resolved with $\mathrm{Ca}(\mathrm{H}-\mathrm{DBTA})_{2}[(R, R)-8]$ according to Representative Procedure detailed in Section 2.2. The exact amounts of resolving agents and solvents are as follows. Phosphine oxide 1 and 7: $0.38 \mathrm{mmol}$ of $\mathrm{Ca}(\mathrm{H}-\mathrm{DBTA})_{2}\left(0.28 \mathrm{~g}\right.$ of DBTA. $\mathrm{H}_{2} \mathrm{O}, 0.021 \mathrm{~g} \mathrm{CaO}, 0.91 \mathrm{~mL}$ of EtOH, $91 \mu \mathrm{L}$ of $\mathrm{H}_{2} \mathrm{O}, 0.91 \mathrm{~mL}$ of EtOAc); phosphine oxide 5: $0.50 \mathrm{mmol}$ of $\mathrm{Ca}(\mathrm{H}-\mathrm{DBTA})_{2}\left(0.38 \mathrm{~g}\right.$ of DBTA $\cdot \mathrm{H}_{2} \mathrm{O}$, $0.028 \mathrm{~g}$ of $\mathrm{CaO}, 1.22 \mathrm{~mL}$ of EtOH, $0.12 \mu \mathrm{L}$ of $\mathrm{H}_{2} \mathrm{O}, 1.22 \mathrm{~mL}$ of EtOAc); phosphine oxide 2, 4 and 6: $0.75 \mathrm{mmol}$ of $\mathrm{Ca}(\mathrm{H}-\mathrm{DBTA})_{2}\left(0.56 \mathrm{~g}\right.$ of DBTA. $\mathrm{H}_{2} \mathrm{O}, 0.042 \mathrm{~g}$ of $\mathrm{CaO}, 1.82 \mathrm{~mL}$ of EtOH, $0.18 \mu \mathrm{L}$ of $\mathrm{H}_{2} \mathrm{O}, 1.82 \mathrm{~mL}$ of EtOAc). The following diastereomeric complexes were prepared: $0.22 \mathrm{~g}(109 \%)$ of $[(R)-1]_{2} \cdot \mathrm{Ca}(\mathrm{H}-\mathrm{DBTA})_{2}$ with a de of $34 \% ; 0.056 \mathrm{~g}(16 \%)$ of $(S)-2 \cdot \mathrm{Ca}(\mathrm{H}-\mathrm{DBTA})_{2}$ with a de of $37 \% ; 0.093 \mathrm{~g}$ $(26 \%)$ of $(S)-4 \cdot \mathrm{Ca}(\mathrm{H}-\mathrm{DBTA})_{2}$ with a de of $75 \% ; 0.23 \mathrm{~g}(91 \%)$ of $[(R)-5]_{3} \cdot \mathrm{Ca}_{2}(\mathrm{H}-\mathrm{DBTA})_{4}$ with a de of $32 \%$; and $0.27 \mathrm{~g}(125 \%)$ of $[(R)-7]_{2} \cdot \mathrm{Ca}(\mathrm{H}-\mathrm{DBTA})_{2}$ with a de of $3 \%$. No diastereomeric complex formed in case of phosphine oxide 6 .

The diastereomeric complexes incorporating phosphine oxide 1, 4, 5 or 7 were decomposed using $10 \%$ aqueous ammonia and dichloromethane according to procedure described in Section 2.3.3 to give $0.067 \mathrm{~g}(106 \%)$ of $(R)-\mathbf{1}$ with an $e e$ of $34 \% ; 0.018 \mathrm{~g}(25 \%)$ of $(S)-4$ with an $e e$ of $75 \% ; 0.060 \mathrm{~g}(88 \%)$ of $(R)-5$ with an $e e$ of $32 \% ; 0.090 \mathrm{~g}(122 \%)$ of (R)-7 with an $e e$ of $3 \%$.

The resulting enantiomeric mixtures of phosphine oxide 1, 4, 5 or 7 were resolved with $\mathrm{Ca}(\mathrm{H}-\mathrm{DBTA})_{2}[(R, R)-8]$ according to Representative Procedure detailed in Section 2.2 [phosphine oxide 1: $0.20 \mathrm{mmol}$ of $\mathrm{Ca}(\mathrm{H}-\mathrm{DBTA})_{2}\left(0.15 \mathrm{~g}\right.$ of DBTA. $\mathrm{H}_{2} \mathrm{O}, 0.011 \mathrm{~g} \mathrm{CaO}, 0.48 \mathrm{~mL}$ of EtOH, $48 \mu \mathrm{L}$ of $\mathrm{H}_{2} \mathrm{O}, 0.48 \mathrm{~mL}$ of EtOAc); phosphine oxide $4: 0.094 \mathrm{mmol}$ of $\mathrm{Ca}(\mathrm{H}-\mathrm{DBTA})_{2}\left(0.071 \mathrm{~g}\right.$ of DBTA $\cdot \mathrm{H}_{2} \mathrm{O}$, $5.3 \mathrm{mg}$ of $\mathrm{CaO}, 0.23 \mathrm{~mL}$ of EtOH, $23 \mu \mathrm{L}$ of $\mathrm{H}_{2} \mathrm{O}, 0.23 \mathrm{~mL}$ of EtOAc); phosphine oxide 5: $0.22 \mathrm{mmol}$ of $\mathrm{Ca}(\mathrm{H}-\mathrm{DBTA})_{2}\left(0.17 \mathrm{~g}\right.$ of DBTA. $\mathrm{H}_{2} \mathrm{O}, 0.012 \mathrm{~g}$ of $\mathrm{CaO}, 0.53 \mathrm{~mL}$ of EtOH, $53 \mu \mathrm{L}$ of $\mathrm{H}_{2} \mathrm{O}, 0.53 \mathrm{~mL}$ of EtOAc); phosphine oxide 7: $0.23 \mathrm{mmol}$ of $\mathrm{Ca}(\mathrm{H}-\mathrm{DBTA})_{2}\left(0.17 \mathrm{~g}\right.$ of DBTA $\cdot \mathrm{H}_{2} \mathrm{O}, 0.013 \mathrm{~g}$ of $\mathrm{CaO}, 0.56 \mathrm{~mL}$ of $\mathrm{EtOH}, 56 \mu \mathrm{L}$ of $\mathrm{H}_{2} \mathrm{O}, 0.56 \mathrm{~mL}$ of EtOAc)] to give $0.15 \mathrm{~g}(73 \%)$ of $[(R)-1]_{2} \cdot \mathrm{Ca}(\mathrm{H}-\mathrm{DBTA})_{2}$ with a de of $66 \% ; 0.028 \mathrm{~g}(8 \%)$ of $(S)-4 \cdot \mathrm{Ca}(\mathrm{H}-\mathrm{DBTA})_{2}$ with a de of $96 \% ; 0.14 \mathrm{~g}(54 \%)$ of $[(R)-5]_{3} \cdot \mathrm{Ca}_{2}(\mathrm{H}-\mathrm{DBTA})_{4}$ with a de of $53 \% ; 0.17 \mathrm{~g}(79 \%)$ of $[(R)-7]_{2} \cdot \mathrm{Ca}(\mathrm{H}-\mathrm{DBTA})_{2}$ with a de of $3 \%$.

The diastereomeric complexes incorporating phosphine oxide $\mathbf{1}$ or $\mathbf{5}$ were decomposed using $10 \%$ aqueous ammonia and dichloromethane according to procedures described in Section 2.3.3 to give $0.044 \mathrm{~g}(70 \%)$ of $(R)-1$ with an $e e$ of $66 \% ; 0.035 \mathrm{~g}(51 \%)$ of $(R)-5$ with an $e e$ of $53 \%$. The resulting enantiomeric mixtures of phosphine oxide 1 or 5 were resolved with $\mathrm{Ca}(\mathrm{H}-\mathrm{DBTA})_{2}[(R, R)-8]$ according to Representative Procedure detailed in Section 2.2 [phosphine oxide 1: $0.13 \mathrm{mmol}$ of $\mathrm{Ca}(\mathrm{H}-\mathrm{DBTA})_{2}$ ( $0.10 \mathrm{~g}$ of DBTA. $\mathrm{H}_{2} \mathrm{O}, 7.4 \mathrm{mg} \mathrm{CaO}, 0.32 \mathrm{~mL}$ of EtOH, $32 \mu \mathrm{L}$ of $\mathrm{H}_{2} \mathrm{O}, 0.32 \mathrm{~mL}$ of EtOAc); phosphine 
oxide 5: $0.13 \mathrm{mmol}$ of $\mathrm{Ca}(\mathrm{H}-\mathrm{DBTA})_{2}\left(0.096 \mathrm{~g}\right.$ of DBTA $\cdot \mathrm{H}_{2} \mathrm{O}, 7.1 \mathrm{mg}$ of $\mathrm{CaO}, 0.31 \mathrm{~mL}$ of EtOH, $31 \mu \mathrm{L}$ of $\mathrm{H}_{2} \mathrm{O}, 0.31 \mathrm{~mL}$ of EtOAc)] to give $0.093 \mathrm{~g}(46 \%)$ of $[(R)-1]_{2} \cdot \mathrm{Ca}(\mathrm{H}-\mathrm{DBTA})_{2}$ with a de of $80 \% ; 0.076 \mathrm{~g}(30 \%)$ of $[(R)-5]_{3} \cdot \mathrm{Ca}_{2}(\mathrm{H}-\mathrm{DBTA})_{4}$ with a de of $69 \%$.

The diastereomeric complexes incorporating phosphine oxide $\mathbf{1}$ or $\mathbf{5}$ were decomposed using $10 \%$ aqueous ammonia and dichloromethane according to the procedure described in Section 2.3.3 to give $0.025 \mathrm{~g}(40 \%)$ of (R)-1 with an ee of $80 \% ; 0.019 \mathrm{~g}(28 \%)$ of $(R)-5$ with an $e e$ of $69 \%$. The resulting enantiomeric mixtures of phosphine oxide 1 or 5 were resolved with $\mathrm{Ca}(\mathrm{H}-\mathrm{DBTA})_{2}[(R, R)-8]$ according to Representative Procedure detailed in Section 2.2 [phosphine oxide 1: $0.075 \mathrm{mmol}$ of $\mathrm{Ca}(\mathrm{H}-\mathrm{DBTA})_{2}$ ( $0.056 \mathrm{~g}$ of DBTA $\cdot \mathrm{H}_{2} \mathrm{O}, 4.2 \mathrm{mg} \mathrm{CaO}, 0.18 \mathrm{~mL}$ of EtOH, $18 \mu \mathrm{L}$ of $\mathrm{H}_{2} \mathrm{O}, 0.18 \mathrm{~mL}$ of EtOAc); phosphine oxide 5: $0.070 \mathrm{mmol}$ of $\mathrm{Ca}(\mathrm{H}-\mathrm{DBTA})_{2}\left(0.053 \mathrm{~g}\right.$ of DBTA $\cdot \mathrm{H}_{2} \mathrm{O}, 3.9 \mathrm{mg}$ of $\mathrm{CaO}, 0.17 \mathrm{~mL}$ of EtOH, $17 \mu \mathrm{L} \mathrm{of} \mathrm{H}_{2} \mathrm{O}$, $0.17 \mathrm{~mL}$ of EtOAc)] to give $0.065 \mathrm{~g}(32 \%)$ of $[(R)-1]_{2} \cdot \mathrm{Ca}(\mathrm{H}-\mathrm{DBTA})_{2}$ with a de of $85 \% ; 0.051 \mathrm{~g}(20 \%)$ of $[(R)-5]_{3} \cdot \mathrm{Ca}_{2}(\mathrm{H}-\mathrm{DBTA})_{4}$ with a de of $80 \%$. The results are summarized in Table 3.

Table 3. Optical resolution of dialkyl-arylphosphine oxides (1, 2 and 4-7) with $\mathrm{Ca}(\mathrm{H}-\mathrm{DBTA})_{2}[(R, R)-8]$ under optimized conditions.

\begin{tabular}{|c|c|c|c|c|c|c|c|}
\hline Entry & $\begin{array}{c}\mathbf{R}^{1}=\mathbf{M e}, \\
\mathbf{R}^{2}=\end{array}$ & $\begin{array}{c}\text { Diastereomeric } \\
\text { Complex }^{a}\end{array}$ & $\begin{array}{c}\text { Number of } \\
\text { Crystallizations }\end{array}$ & $\begin{array}{c}\text { Yield }^{b} \\
(\%)\end{array}$ & $\begin{array}{l}E e^{\mathrm{c}} \\
(\%)\end{array}$ & $\begin{array}{l}S^{d} \\
(-)\end{array}$ & $\begin{array}{c}\text { Abs. } \\
\text { Config. }\end{array}$ \\
\hline \multirow{4}{*}{1} & \multirow{4}{*}{ Et (1) } & \multirow{4}{*}{$(\mathbf{1})_{2} \cdot \mathrm{Ca}(\mathrm{H}-\mathrm{DBTA})_{2}$} & I. & 109 & 34 & 0.37 & \multirow{4}{*}{$(R)$} \\
\hline & & & II. & 73 & 66 & 0.48 & \\
\hline & & & III. & 46 & 80 & 0.36 & \\
\hline & & & IV. & 32 & 85 & 0.27 & \\
\hline 2 & $\operatorname{Pr}(2)$ & $(2) \cdot \mathrm{Ca}(\mathrm{H}-\mathrm{DBTA})_{2}$ & I. & 16 & 37 & 0.06 & $(S)$ \\
\hline \multirow{2}{*}{3} & \multirow{2}{*}{$\mathrm{Bu}(4)$} & \multirow{2}{*}{ (4) $\cdot \mathrm{Ca}(\mathrm{H}-\mathrm{DBTA})_{2}$} & I. & 26 & 75 & 0.20 & \multirow{2}{*}{$(S)$} \\
\hline & & & II. & 8 & 96 & 0.08 & \\
\hline \multirow{3}{*}{$4^{\mathrm{f}}$} & \multirow{3}{*}{$\mathrm{Bu}(4)$} & \multirow{3}{*}{ (4) $\cdot \mathrm{Ca}(\mathrm{H}-\mathrm{DBTA})_{2}$} & I. & 69 & 54 & 0.37 & \multirow{3}{*}{$(S)$} \\
\hline & & & II. & 34 & 86 & 0.29 & \\
\hline & & & III. & 17 & 96 & 0.16 & \\
\hline \multirow{4}{*}{5} & \multirow{4}{*}{$i-\operatorname{Pr}(5)$} & \multirow{4}{*}{$(5)_{3} \cdot \mathrm{Ca}_{2}(\mathrm{H}-\mathrm{DBTA})_{4}$} & I. & 91 & 32 & 0.29 & \multirow{4}{*}{$(R)$} \\
\hline & & & II. & 54 & 53 & 0.29 & \\
\hline & & & III. & 30 & 69 & 0.21 & \\
\hline & & & IV. & 20 & 80 & 0.16 & \\
\hline 6 & $c$-Hex (6) & no complex & - & - & - & - & - \\
\hline \multirow{2}{*}{7} & \multirow{2}{*}{$t-\mathrm{Bu}(7)$} & \multirow{2}{*}{$(7)_{2} \cdot \mathrm{Ca}(\mathrm{H}-\mathrm{DBTA})_{2}$} & I. & 125 & 3 & 0.04 & \multirow{2}{*}{$(R)$} \\
\hline & & & II. & 79 & 3 & 0.03 & \\
\hline
\end{tabular}

${ }^{a}$ Ratio of phosphine oxides $(\mathbf{1}, \mathbf{2}, 4-7)$ and resolving agent was determined by ${ }^{1} \mathrm{H}$ NMR. ${ }^{\mathrm{b}}$ Yield of the diastereomer was calculated based on half of the racemic phosphine oxides $(\mathbf{1}, \mathbf{2}, \mathbf{4}-\mathbf{7})$ that is regarded to be $100 \%$ for each antipode. ${ }^{\mathrm{c}}$ Determined by HPLC using a chiral stationary phase. ${ }^{\mathrm{d}}$ Resolving capability, also known as the Fogassy parameter $[S(-)=($ Yield $[\%] / 100) \times(e e[\%] / 100)] .{ }^{\text {e }}$ Absolute configuration of phosphine oxides $(\mathbf{1}, \mathbf{2}, \mathbf{4}-7)$ was determined by specific rotation. ${ }^{\mathrm{f}}$ Resolution and the purification were carried out using half amount of solvents.

\section{Results and Discussion}

\subsection{Optimization of Optical Resolution of Ethyl-Phenyl-Propylphosphine Oxide (3)}

For optimizing the conditions of the optical resolution, ethyl-phenyl-propylphosphine oxide (3) was selected as model racemate, as it has an average size within the dialkyl-arylphosphine oxides (1-7) investigated in this study.

As coordination of the chiral tartaric acid scaffold and phosphine oxide to the cation is one of the most important interactions in the diastereomers formed, $(-)-O, O^{\prime}$-dibenzoyl-(2R,3R)-tartaric acid was converted to its calcium-, magnesium-, copper-, nickel- or cobalt-salts to test which derivative is the most suitable for enantiomeric separation of ethyl-phenyl-propylphosphine oxide (3). Interestingly, only the acidic $\mathrm{Ca}^{2+}$-salt of (-)-O,O'-dibenzoyl-(2R,3R)-tartaric acid $[(R, R)-8]$ led to the formation of crystalline diastereomers, and to partial enantiomeric separation of phosphine oxide 3 (ee: $44 \%$, yield 
$83 \%)$. Using other metal salts, no crystals were formed, indicating that coordination of either tartaric acid or phosphine oxide (3) is low towards magnesium-, copper-, nickel- or cobalt (See Supplementary Material for details).

With the most suitable metal salt in hand, we started our optimization studies. The corresponding resolving agent $[(R, R)-8-(R, R)-\mathbf{1 1}]$ can either be prepared prior to reaction, or it can be formed in situ by reacting the given tartaric acid derivative with $\mathrm{CaO}$ in a mixture of ethanol and water. Besides $(-)-O, O^{\prime}$-dibenzoyl-(2R,3R)-tartaric acid, (-)-O, $O^{\prime}-p$-toluoyl-(2R,3R)-tartaric acid can also be used as chiral moiety. Moreover, $\mathrm{Ca}^{2+}$-salt of a given tartaric acid derivative can also be prepared in an acidic or neutral form $[(R, R)-8-(R, R)-11]$, in which the ratio of $\mathrm{Ca}^{2+}$ and the given tartaric acid derivative is different. In our first few optimization experiments, we intended to select the most efficient resolution procedure, as well as the best tartaric acid derivative and its $\mathrm{Ca}^{2+}$-salt form $[(R, R)-8-(R, R)-\mathbf{1 1}]$ (Scheme 1$)$. In the optimization experiments, results obtained after the first crystallization were evaluated and compared, and the diastereomeric complexes were not purified further. Composition of the given diastereomer was determined by ${ }^{1} \mathrm{H}$ NMR, and enantiomeric excess of phosphine oxide 3 was measured by HPLC using a chiral stationary phase. Results are summarized in Table 1.

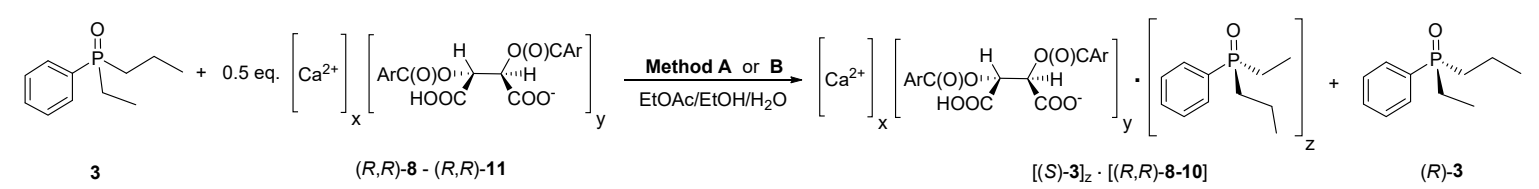

Method A = The resolving agent was prepared "in situ"

Method B = Pre-made resolving agent

$x, y$ or $z$ : See Table 1.

Scheme 1. Optical resolution of ethyl-phenyl-propylphosphine oxide (3) with different $\mathrm{Ca}^{2+}$ salts of tartaric-acid derivatives $[(R, R)-8-(R, R)-\mathbf{1 1}]$.

Results indicated, that higher enantiomeric excess and resolving capability values (i.e., higher efficiency) could be achieved when ethyl-phenyl-propylphosphine oxide (3) is resolved with $\mathrm{Ca}(\mathrm{H}-\mathrm{DBTA})_{2}$ $[(R, R)-8]$ prepared in situ, in contrary to the case when a pre-made resolving agent $[(R, R)-8]$ is used (Table 1, Entries 1-2). Besides the difference in the experimental procedure, 10\% of water used for in situ preparation of $\mathrm{Ca}(\mathrm{H}-\mathrm{DBTA})_{2}$ may be another reason for the improved results.

Comparing different tartaric acid derivatives and their $\mathrm{Ca}^{2+}$-salts, one can conclude that the best derivative for enantiomeric separation of phosphine oxide 3 is the acidic $\mathrm{Ca}^{2+}$-salt of dibenzoyl-(2R,3R)-tartaric acid [Ca(H-DBTA $\left.)_{2} ;(R, R)-8\right]$ (Table 1, Entry 2). Changing the chiral scaffold from dibenzoyl-tartaric acid to di-p-toluoyl-tartaric acid, or using neutral salt instead of acidic salts did not lead to improved results (Compare Table 1, Entry 2 with Entries 3-5). In general, better enantiomeric separation of phosphine oxide 3 was obtained with acidic salts $[(R, R)-8$ or $(R, R)-9]$ than with neutral salts $[(R, R)-\mathbf{1 0}$ or $(R, R)-11]$ (Compare Table 1, Entries 2 and 3 or Entries 4 and 5). Resolving agents $\mathrm{Ca}(\mathrm{H}-\mathrm{DBTA})_{2}$ and $\mathrm{Ca}(\mathrm{H}-\mathrm{DPTTA})_{2}[(R, R)-8$ or $(R, R)-9]$ contain $\mathrm{Ca}^{2+}$ and the corresponding tartaric acid derivative in a 1:2 ratio. Our previous studies revealed [57,58], that this stoichiometric ratio allows the formation of polymer-like catena structures, that stabilize the crystal structure of the diastereomer, and leads to improved enantiomeric separation of the given phosphine oxide coordinating to the $\mathrm{Ca}^{2+}$ ion.

The experimental results summarized in Table 1 indicated that the best $e e$ and resolving capability $(S)$ values can be obtained with $\mathrm{Ca}(\mathrm{H}-\mathrm{DBTA})_{2}[(R, R)-8]$ prepared in situ. As the next step, we optimized solvents, solvent composition, amount of resolving agent $(R, R)-8$ and crystallization time applied for enantiomeric separation of phosphine oxide 3. $\mathrm{Ca}(\mathrm{H}-\mathrm{DBTA})_{2}[(R, R)-8]$ was always prepared in situ, by refluxing $(-)-O, O^{\prime}$-dibenzoyl-( $\left.2 R, 3 R\right)$-tartaric acid in a mixture of ethanol and water. Then the solution of ethyl-phenyl-propylphosphine oxide (3) was immediately added to the resolving agent $[(R, R)-8]$. The diastereomeric complex that precipitated from the solution upon cooling was crystallized for $24 \mathrm{~h}$, and then it was separated from the mother liquor by filtration (Scheme 2). Enantiomeric mixture of phosphine oxide 3 could be liberated from the diastereomer by extraction with aqueous $\mathrm{NH}_{4} \mathrm{OH}$ and dichloromethane. Results are summarized in Table 2. 


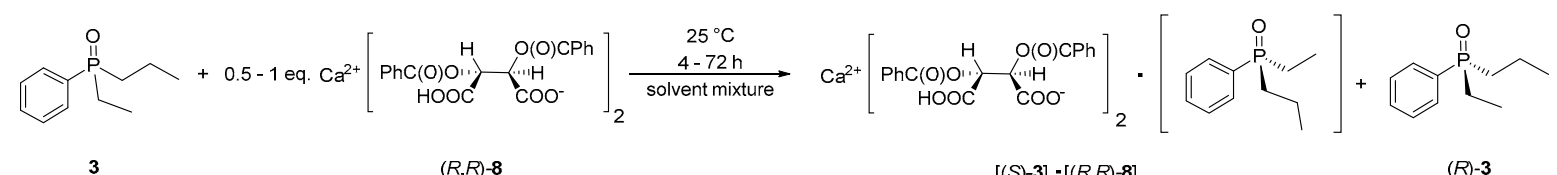

Scheme 2. Optimization of crystallization conditions for resolution of ethyl-phenyl-propylphosphine oxide (3) with $\mathrm{Ca}(\mathrm{H}-\mathrm{DBTA})_{2}[(R, R)-8]$ prepared in situ.

In the preliminary experiments (Table 1, Entries 1 and 2), coordination complexes were obtained with a composition of (3) $\cdot \mathrm{Ca}(\mathrm{H}-\mathrm{DBTA})_{2}$. Thus, resolution of ethyl-phenyl-propylphosphine oxide (3) was first attempted using 0.5 equivalent of $\mathrm{Ca}(\mathrm{H}-\mathrm{DBTA})_{2}[(R, R)-8]$ (i.e., according to half-equivalent method) (Table 2, Entries 1-9). Both components of the solvent mixture were changed systematically. It is noteworthy that resolving agent $\mathrm{Ca}(\mathrm{H}-\mathrm{DBTA})_{2}[(R, R)-8]$ can only be prepared in an alcohol using a sufficient amount of water. Thus, $\mathrm{Ca}(\mathrm{H}-\mathrm{DBTA})_{2}[(R, R)-8]$ was formed in situ in either methanol, ethanol or 2-propanol. Ethyl acetate, butyl acetate, ethanol, acetone, acetonitrile or toluene was the other solvent used for the dissolution of ethyl-phenyl-propylphosphine oxide (3). 1:1 Ratio of the two solvents was kept constant throughout the solvent optimization experiments (Table 2, Entries 1-9).

Results indicated that ethanol is the most suitable alcohol for the resolution investigated, as the use of methanol or 2-propanol led to lower yields or ee values of phosphine oxide 3 (Compare Table 2, Entry 1 with Entries 2 and 3). Considering the other component of the solvent mixture, the best results were obtained with ethyl acetate (Table 2, Entry 1). Using butyl acetate, resolving capability value showed parity to the ethyl acetate case, but the ee of 3 was lower (Compare Table 2, Entries 1 and 4). Both yield and $e e$ of phosphine oxide 3 were significantly lower when acetone, acetonitrile or toluene was used as solvent (Table 2, Entries 5-7). Interestingly, the mixture of ethanol and ethyl acetate was necessary to obtain the best results, as lower $e e$ and resolving capability values were obtained when ethanol or ethyl acetate was exclusively used for crystallization (Compare Table 2, Entry 1 with Entries 8 and 9). In the latter case, the resolution procedure was altered. Ethanol solution containing the in situ formed resolving agent $[(R, R)-8]$ and racemic phosphine oxide 3 was evaporated to dryness, and the solid material was suspended in ethyl acetate.

The amount of resolving agent $[(R, R)-8]$ and the composition of the solvent mixture were also optimized (Table 2, Entries 10-16). Results showed that optical resolution of ethyl-phenylpropylphosphine oxide (3) is more efficient when 1 equivalent of $\mathrm{Ca}(\mathrm{H}-\mathrm{DBTA})_{2}$ is used (i.e., according to equivalent method), which indicates that the separation of two diastereomeric species $\left[(S)-3 \cdot \mathrm{Ca}(\mathrm{H}-\mathrm{DBTA})_{2}\right.$ and $\left.(R)-3 \cdot \mathrm{Ca}(\mathrm{H}-\mathrm{DBTA})_{2}\right]$ by crystallization is easier than the separation of $(S)-3 \cdot \mathrm{Ca}(\mathrm{H}-\mathrm{DBTA})_{2}$ diastereomer from the enantiomeric mixture containing $(R)-3$ in excess. Changing either concentration during crystallization (Table 2, Entries 11 and 12), or the ratio of ethanol and ethyl acetate in the solvent mixture (Table 2, Entries 13 and 14) did not lead to better ee and resolving capability values. Interestingly, the amount of water had a significant influence on the resolution efficiency. Throughout the optimization studies, water used was kept constant. When half amount of water was used, the yield of (S)-3.Ca(H-DBTA $)_{2}$ increased to $97 \%$ from $79 \%$, but the de of the diastereomer dropped to $56 \%$ from $74 \%$, giving an overall resolving capability value of 0.54 , which is comparable to the original results $(S=0.54)$. In contrast, double amount of water in the solvent mixture led to the formation of no diastereomeric complexes but the precipitation of the resolving agent $[(R, R)-8]$ (Compare Table 2, Entries 10, 15 and 16). The fact that the amount of strong $H$-bond donor and acceptor water had such a big influence of resolution efficiency indicates that $H$-bonds formed between the resolving agent $[(R, R)-8]$ and phosphine oxide 3 may play a significant role in the formation of diastereomers, the crystallization process and consequently in enantiomeric recognition.

During the optimization studies, (S)-3.Ca(H-DBTA $)_{2}$ diastereomers were allowed to crystallize for $24 \mathrm{~h}$. Two experiments were also conducted with $4 \mathrm{~h}$ or $72 \mathrm{~h}$ of crystallization time (see Supplementary Material for details). The results indicated that resolution of phosphine oxide 3 with $\mathrm{Ca}(\mathrm{H}-\mathrm{DBTA})_{2}$ $[(R, R)-8]$ is a thermodynamically controlled resolution, as no kinetic enhancement could be observed 
with a shortened crystallization time, and thermodynamic equilibrium can be reached after $24 \mathrm{~h}$ of crystallization and there is no point for extending the crystallization time.

Considering the results of the optimization studies (Tables 1 and 2), the most efficient enantiomeric separation of phosphine oxide 3 could be obtained with $\mathrm{Ca}(\mathrm{H}-\mathrm{DBTA})_{2}$ in a 1:1 mixture of ethyl acetate and ethanol, and (S)-3 could be obtained with an $e e$ of $74 \%$ after the first crystallization. Different purification strategies of enantiomeric mixtures of (S)-ethyl-phenyl-propylphosphine oxide [(S)-3] were then evaluated, as it is also an integral part of every resolution procedure [59].

Three separate methods were tested, and the diastereomer of (S)-3.Ca(H-DBTA $)_{2}$ prepared with a de of $74 \%$ under optimal reaction conditions were used in these experiments. Crystals of $(S)-3 \cdot \mathrm{Ca}(\mathrm{H}-\mathrm{DBTA})_{2}$ were stirred at room temperature in a mixture of ethanol, ethyl acetate and water (digestion) (Scheme 3/II), or the diastereomer was recrystallized from the same solvent mixture (Scheme 3/III). The third purification method involved decomposition of (S)-3. $\mathrm{Ca}(\mathrm{H}-\mathrm{DBTA})_{2}$ diastereomeric complex, followed by repeated resolution of the enantiomeric mixture of (S)-ethyl-phenyl-propylphosphine oxide [(S)-3] with 1 equivalent of $\mathrm{Ca}(\mathrm{H}-\mathrm{DBTA})_{2}[(R, R)-8]$ under optimal crystallization conditions (Scheme $3 / \mathrm{IV}$ and V). The results indicated that digestion was the least effective purification method, as de of (S)-3.Ca(H-DBTA $)_{2}$ diastereomer increased from $74 \%$ to $77 \%$. Using either recrystallization or repeated resolution, diastereomeric purity reached $94 \%$ or $93 \%$, respectively. Repeated resolution gave somewhat better yields ( $48 \%$ vs. $43 \%$ ). As ethyl-phenyl-propylphosphine oxide (3) is an oily substrate at room temperature, the corresponding enantiomeric mixtures $[(S)-3]$ could not be purified further by recrystallization without using any resolving agent or chiral additive.

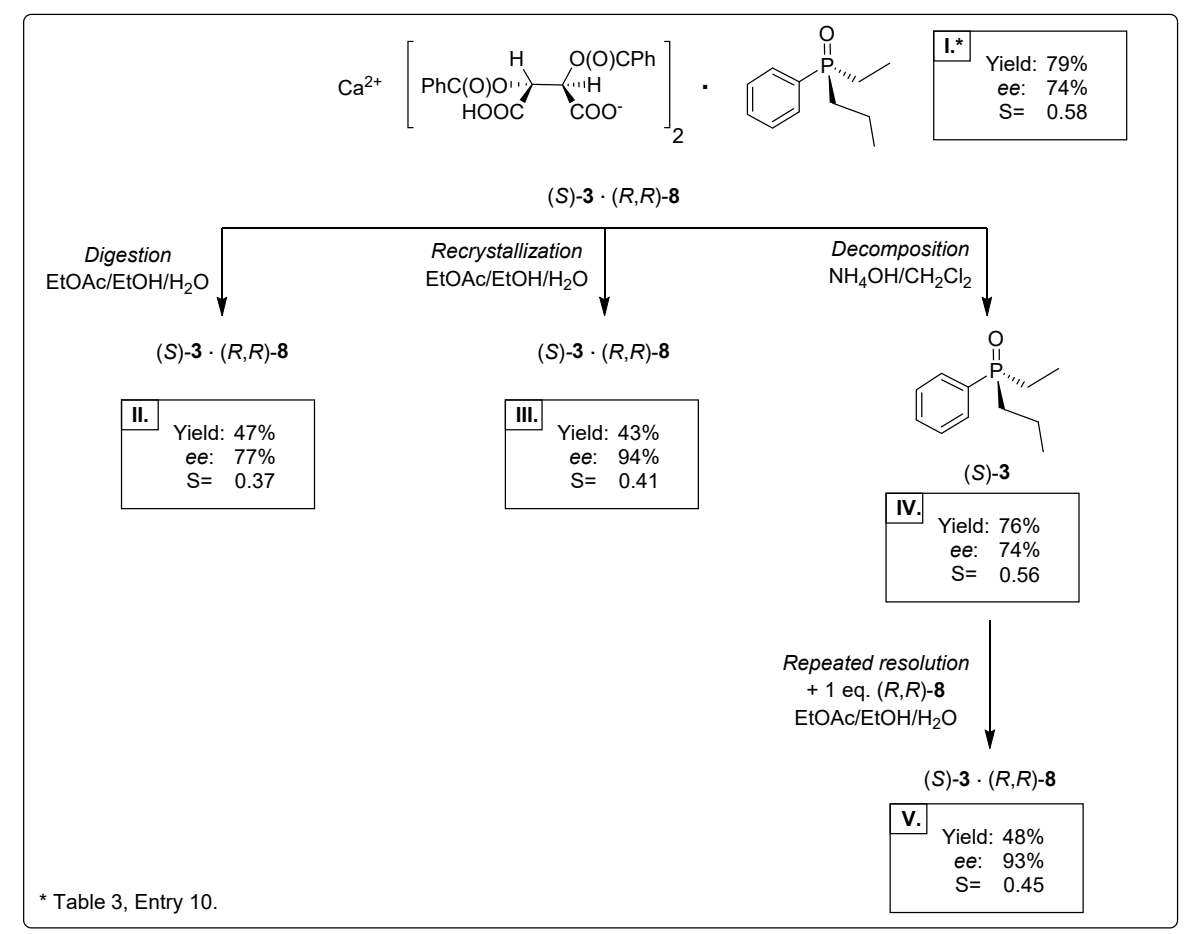

Scheme 3. Purification possibilities of enantiomeric mixtures of (S)-ethyl-phenyl-propylphosphine oxide $[(S)-3]$.

3.2. Optical Resolution of Dialkyl-Arylphosphine Oxides (1, 2 and 4-7) with $C a(H-D B T A)_{2}[(R, R)-8]$ under Optimized Conditions

As the last step of this study, resolution of other dialkyl-arylphosphine oxides $(\mathbf{1}, \mathbf{2}$ and $4-7)$ was also attempted with $\mathrm{Ca}(\mathrm{H}-\mathrm{DBTA})_{2}[(R, R)-8]$ under optimal conditions. The resolving agent $[(R, R)-8]$ was prepared in situ, a mixture of ethyl acetate, ethanol and water was used as solvent, crystallization time was $24 \mathrm{~h}$, and the enantiomeric mixtures of the corresponding phosphine oxides were purified by repeated resolution. In a few instances, the corresponding diastereomer was crystallized several 
times in order to reach high enantiomeric excess values. Resolutions were carried out according to the equivalent method (Scheme 4).

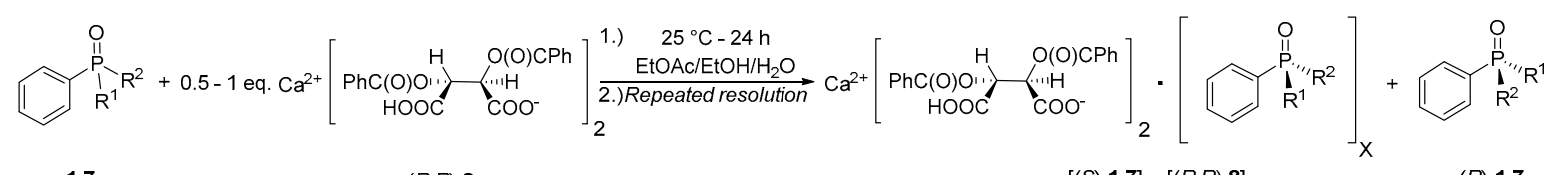

$1-7$

$(R, R)-8$

$[(S)-1-7]_{x} \cdot[(R, R)-8]$

$(R)-1-7$

Scheme 4. Optical resolution of dialkyl-arylphosphine oxides (1, 2 and 4-7) with $\mathrm{Ca}(\mathrm{H}-\mathrm{DBTA})_{2}[(R, R)-8]$ under optimized conditions.

The results summarized in Table 3 show that the structure of phosphine oxide (1,2 and 4-7) had a significant influence on the efficiency of the resolution. (S)-Butyl-methyl-phenylphosphine oxide [(S)-4] could be prepared with a maximal ee of $96 \%$ after the second crystallization under optimized conditions, but yield of the corresponding phosphine oxide (S)-4, and consequently, efficiency of the resolution was rather low (Table 3, Entry 3). In order to increase the resolving capability values, resolution was carried out in half amount of solvent, and the diastereomer were crystallized three times. This change increased yield from $8 \%$ to $17 \%$, and enantiomeric excess of (S)-4 reached also $96 \%$ after purifications (Table 3, Entry 4).

Four crystallizations were necessary, to obtain optically active ethyl-methyl-phenylphosphine-oxide $[(R)-1]$ and methyl-phenyl-i-propylphosphine oxide $[(R)-5]$ with an $e e$ of $85 \%$ or $80 \%$, respectively (Table 3 , Entries 1 and 5). However, yield of the corresponding diastereomers was lower than $32 \%$, thus no additional purifications were used in these instances. Interestingly, $\mathrm{MePrPhP}(\mathrm{O})(2)$ could not be resolved efficiently (ee 37\%) (Table 3, Entry 2), despite the fact that this phosphine oxide was in close structural resemblance to other $P$-oxides used in this study.

$c$-Hexyl- and $t$-butyl-methyl-phenylphosphine oxides (6 and 7) could be resolved with the lowest efficiency, as no crystalline diastereomeric complexes were formed for phosphine oxide 6 , whereas $e e$ of the $t$-butyl-derivative (7) was only $3 \%$ (Table 3, Entry 6 and 7). These results indicated, that the increased steric demand cyclohexyl- or $t$-butyl-groups may hinder non-covalent interactions responsible for enantiomeric recognition, which leads to inefficient enantiomeric separation of these two phosphine oxides (6 and 7$)$.

Interestingly, composition of the diastereomeric complex also varied in case of resolution of different phosphine oxide derivatives (1-7). Diastereomers incorporating the corresponding phosphine oxides and dibenzoyl-(2R,3R)-tartaric acid in a 1:2 ratio were obtained during the resolution of phosphine oxides 2-4 (Scheme 3; Table 3, Entries 2-4). However, this ratio changed to 1:1 or 3:4 when enanatiomeric separation of ethyl-, $i$-propyl- or $t$-butyl-methyl-phenylphosphine oxides $(\mathbf{1}, \mathbf{5}$ and $\mathbf{7})$ was elaborated (Table 3, Entries 1,5 and 7). This change in the composition of the diastereomers may indicate a change in second order interactions responsible for enantiomeric recognition.

\section{Conclusions}

In conclusion, this study demonstrated that the coordination mediated optical resolution method originally developed for cyclic phosphine oxides has a more general scope, and this technique can be used for acyclic phosphine oxides. Enantiomeric separation of a few dialkyl-phenylphosphine oxides (1-5 and 7) was elaborated with metals salts of tartaric acid derivatives. The resolution procedure, crystallization and purification conditions were optimized, and the most efficient enantioseparation was obtained with acidic $\mathrm{Ca}^{2+}$-salt (-)-O, $O^{\prime}$-dibenzoyl-(2R,3R)-tartaric acid $[(R, R)-8]$. The $(S)$ enantiomer ethyl-phenyl-propylphosphine oxide [(S)-3] and butyl-methyl-phenylphosphine oxide [(S)-4] was prepared with enantiomeric excess higher than $93 \%$. On the other hand, enantiomeric mixtures of ethyl-, propyl and $i$-propyl-methyl-phenylphosphine oxide $[(R)-\mathbf{1},(S)-\mathbf{2}$ and $(R)$-5] was obtained with $e e$ being the range of $37-85 \%$. Optical resolution of $c$-hexyl- and $t$-butyl-methyl-phenylphosphine oxides ( 6 and 7) was unsuccessful, likely due to the increased steric bulk of the branched alkyl groups. 
Supplementary Materials: Details of chemicals, instruments used in this study, a few synthetic procedures, the characterization of the enantiomeric mixtures of phosphine oxides (1-7), as well as HPLC traced can be found in the Supplementary Material: http://www.mdpi.com/2073-8994/12/2/215/s1.

Author Contributions: Conceptualization, B.V. and P.B.; methodology, B.V.; validation, P.B.; formal analysis, B.V.; data curation, B.V.; writing-original draft preparation, B.V.; writing-review and editing, P.B.; visualization, B.V.; supervision, P.B.; project administration, P.B.; funding acquisition, P.B. All authors have read and agreed to the published version of the manuscript.

Funding: This work was supported by the National Research, Development and Innovation Office-NKFIH (Grant No. OTKA PD 116096). Support of grant BME FIKP-BIO by Ministry of Human Capacities of Hungary (EMMI) is kindly acknowledged.

Conflicts of Interest: The authors declare no conflict of interest.

\section{References}

1. Börner, A. (Ed.) Phosphorus Ligands in Asymmetric Catalysis: Synthesis and Applications; Wiley-VCH: Weinheim, Germany, 2008.

2. Grabulosa, A. P-Stereogenic Ligands in Enantioselective Catalysis; The Royal Society of Chemistry: Cambridge, UK, 2010.

3. Dutartre, M.; Bayardon, J.; Jugé, S. Applications and stereoselective syntheses of P-chirogenic phosphorus compounds. Chem. Soc. Rev. 2016, 45, 5771-5794. [CrossRef]

4. Kamer, P.C.J.; Van Leeuwen, P.W.N.M. (Eds.) Phosphorus(III)Ligands in Homogeneous Catalysis: Design and Synthesis; John Wiley \& Sons: New York, NY, USA, 2012.

5. Imamoto, T. Searching for practically useful P-chirogenic phosphine ligands. Chem. Rec. 2016, 16, $2655-2669$. [CrossRef]

6. Xiao, Y.; Sun, Z.; Guo, H.; Kwon, O. Chiral phosphines in nucleophilic organocatalysis. Beilstein J. Org. Chem. 2014, 10, 2089-2121. [CrossRef]

7. Guo, H.; Fan, Y.C.; Sun, Z.; Wu, Y.; Kwon, O. Phosphine organocatalysis. Chem. Rev. 2018, 118, $10049-10293$. [CrossRef]

8. Ni, H.; Chan, W.-L.; Lu, Y. Phosphine-catalyzed asymmetric organic reactions. Chem. Rev. 2018, 118, 9344-9411. [CrossRef]

9. Benaglia, M.; Rossi, S. Chiral phosphine oxides in present-day organocatalysis. Org. Biomol. Chem. 2010, 8 , 3824-3830. [CrossRef]

10. Ayad, T.; Gernet, A.; Pirat, J.-L.; Virieux, D. Enantioselective reactions catalyzed by phosphine oxides. Tetrahedron 2019, 75, 4385-4418. [CrossRef]

11. Liu, S.; Kumatabara, Y.; Shirakawa, S. Chiral quaternary phosphonium salts as phase-transfer catalysts for environmentally benign asymmetric transformations. Green Chem. 2016, 18, 331-341. [CrossRef]

12. Golandaj, A.; Ahmad, A.; Ramjugernath, D. Phosphonium salts in asymmetric catalysis: A journey in a decade's extensive research work. Adv. Synth. Catal. 2017, 359, 3676-3706. [CrossRef]

13. Knowles, W.S. Asymmetric Hydrogenations (Nobel Lecture). Angew. Chem. Int. Ed. 2002, 41, $1998-2007$. [CrossRef]

14. Beaud, R.; Phipps, R.J.; Gaunt, M.J. Enantioselective Cu-catalyzed arylation of secondary phosphine oxides with diaryliodonium salts toward the synthesis of P-chiral phosphines. J. Am. Chem. Soc. 2016, 138, 13183-13186. [CrossRef] [PubMed]

15. Liu, X.-T.; Zhang, Y.-Q.; Han, X.-Y.; Sun, S.-P.; Zhang, Q.-W. Ni-Catalyzed asymmetric allylation of secondary phosphine oxides. J. Am. Chem. Soc. 2019, 141, 16584-16589. [CrossRef] [PubMed]

16. Korpiun, O.; Lewis, R.A.; Chickos, J.; Mislow, K. Synthesis and absolute configuration of optically active phosphine oxides and phosphinates. J. Am. Chem. Soc. 1968, 90, 4842-4846. [CrossRef]

17. Andersen, N.G.; Ramsden, P.D.; Che, D.Q.; Parvez, M.; Keay, B.A. A simple resolution procedure using the Staudinger reaction for the preparation of P-stereogenic phosphine oxides. J. Org. Chem. 2001, 66, 7478-7486. [CrossRef]

18. Oliana, M.; King, F.; Horton, P.N.; Hursthouse, M.B.; Hii, K.K. Practical synthesis of chiral vinylphosphine oxides by direct nucleophilic substitution. Stereodivergent synthesis of aminophosphine ligands. J. Org. Chem. 2006, 71, 2472-2479. [CrossRef] 
19. Adams, H.; Collins, R.C.; Jones, S.; Warner, C.J.A. Enantioselective preparation of P-chiral phosphine oxides. Org. Lett. 2011, 13, 6576-6579. [CrossRef]

20. Chaux, F.; Frynas, S.; Laureano, H.; Salomon, C.; Morata, G.; Auclair, M.-L.; (Massoud) Stephan, M.; Merdès, R.; Richard, P.; Ondel-Eymin, M.-J.; et al. Enantiodivergent synthesis of P-chirogenic phosphines. C. R. Chim. 2010, 13, 1213-1226. [CrossRef]

21. Han, Z.S.; Goyal, N.; Herbage, M.A.; Sieber, J.D.; Qu, B.; Xu, Y.; Li, Z.; Reeves, J.T.; Desrosiers, J.-N.; $\mathrm{Ma}, \mathrm{S}$; ; et al. Efficient asymmetric synthesis of P-chiral phosphine oxides via properly designed and activated benzoxazaphosphinine-2-oxide agents. J. Am. Chem. Soc. 2013, 135, 2474-2477. [CrossRef]

22. Copey, L.; Jean-Gérard, L.; Framery, E.; Pilet, G.; Robert, V.; Andrioletti, B. Experimental and theoretical investigations of the stereoselective synthesis of P-stereogenic phosphine oxides. Chem. Eur. J. 2015, 21, 9057-9061. [CrossRef]

23. D’Onofrio, A.; Copey, L.; Jean-Gérard, L.; Goux-Henry, C.; Pilet, G.; Andrioletti, B.; Framery, E. D-Glucosamine as a novel chiral auxiliary for the stereoselective synthesis of P-stereogenic phosphine oxides. Org. Biomol. Chem. 2015, 13, 9029-9034. [CrossRef]

24. Li, S.-G.; Yuan, M.; Topic, F.; Han, Z.S.; Senanayake, C.H.; Tsantrizos, Y.S. Asymmetric library synthesis of P-chiral t-butyl-substituted secondary and tertiary phosphine oxides. J. Org. Chem. 2019, 84, 7291-7302. [CrossRef] [PubMed]

25. Haynes, R.K.; Au-Yeung, T.-L.; Chan, W.-K.; Lam, W.-L.; Li, Z.-Y.; Yeung, L.-L.; Chan, A.S.C.; Li, P.; Koen, M.; Mitchell, C.R.; et al. Reaction of metallated tert-butyl(phenyl)phosphane oxide with electrophiles as a route to functionalized tertiary phosphane oxides: Alkylation reactions. Eur. J. Org. Chem. 2000, 2000, 3205-3216. [CrossRef]

26. Xu, Q.; Zhao, C.-Q.; Han, L.-B. Stereospecific nucleophilic substitution of optically pure H-phosphinates: A general way for the preparation of chiral P-stereogenic phosphine oxides. J. Am. Chem. Soc. 2008, 130, 12648-12655. [CrossRef] [PubMed]

27. Han, Z.S.; Wu, H.; Xu, Y.; Zhang, Y.; Qu, B.; Li, Z.; Caldwell, D.R.; Fandrick, K.R.; Zhang, L.; Roschangar, F.; et al. General and stereoselective method for the synthesis of sterically congested and structurally diverse P-stereogenic secondary phosphine oxides. Org. Lett. 2017, 19, 1796-1799. [CrossRef] [PubMed]

28. Chrzanowski, J.; Krasowska, D.; Urbaniak, M.; Sieroń, L.; Pokora-Sobczak, P.; Demchuk, O.M.; Drabowicz, J. Synthesis of enantioenriched aryl-tert-butylphenylphosphine oxides via cross-coupling reactions of tert -butylphenylphosphine oxide with aryl halides. Eur. J. Org. Chem. 2018, 2018, 4614-4627. [CrossRef]

29. Kiełbasiński, P.; Źurawiński, R.; Pietrusiewicz, K.M.; Zabłocka, M.; Mikołajczyk, M. Enzymatic resolution of racemic phosphinoylacetates having a stereogenic phosphorus atom. Tetrahedron Lett. 1994, 35, 7081-7084. [CrossRef]

30. Kaczmarczyk, S.; Kwiatkowska, M.; Madalińska, L.; Barbachowska, A.; Rachwalski, M.; Błaszczyk, J.; Sieron, L.; Kiełbasiński, P. Enzymatic synthesis of enantiopure precursors of chiral bidentate and tridentate phosphorus catalysts. Adv. Synth. Catal. 2011, 353, 2446-2454. [CrossRef]

31. Shioji, K.; Ueno, Y.; Kurauchi, Y.; Okuma, K. Lipase-catalyzed kinetic resolution of P-chiral phosphorus compounds: Enantiopreference of Pseudomonas lipase and Candida antarctica lipase. Tetrahedron Lett. 2001, 42, 6569-6571. [CrossRef]

32. Zhang, Y.; He, H.; Wang, Q.; Cai, Q. Asymmetric synthesis of chiral P-stereogenic triaryl phosphine oxides via Pd-catalyzed kinetic arylation of diaryl phosphine oxides. Tetrahedron Lett. 2016, 57, 5308-5311. [CrossRef]

33. Fernández-Pérez, H.; Vidal-Ferran, A. Stereoselective catalytic synthesis of P-stereogenic oxides via hydrogenative kinetic resolution. Org. Lett. 2019, 21, 7019-7023. [CrossRef]

34. Bergin, E.; O'Connor, C.T.; Robinson, S.B.; McGarrigle, E.M.; O’Mahony, C.P.; Gilheany, D.G. Synthesis of P-stereogenic phosphorus compounds. Asymmetric oxidation of phosphines under Appel conditions. J. Am. Chem. Soc. 2007, 129, 9566-9567. [CrossRef]

35. Nikitin, K.; Rajendran, K.V.; Müller-Bunz, H.; Gilheany, D.G. Turning regioselectivity into stereoselectivity: Efficient dual resolution of P-stereogenic phosphine oxides through bifurcation of the reaction pathway of a common intermediate. Angew. Chem. Int. Ed. 2014, 53, 1906-1909. [CrossRef] [PubMed]

36. Rajendran, K.V.; Nikitin, K.V.; Gilheany, D.G. Hammond postulate mirroring enables enantiomeric enrichment of phosphorus compounds via two thermodynamically interconnected sequential stereoselective processes. J. Am. Chem. Soc. 2015, 137, 9375-9381. [CrossRef] [PubMed] 
37. Kortmann, F.A.; Chang, M.-C.; Otten, E.; Couzijn, E.P.A.; Lutz, M.; Minnaard, A.J. Consecutive dynamic resolutions of phosphine oxides. Chem. Sci. 2014, 5, 1322-1327. [CrossRef]

38. Ironmonger, A.; Shipton, M.; Slater, F.; Szeto, P.; Unthank, M.G.; Alexandre, F.R.; Caillet, C.; Dousson, C.B. A highly diastereoselective chloride-mediated dynamic kinetic resolution at phosphorus on-route to a key intermediate in the synthesis of GSK2248761A. Tetrahedron Lett. 2018, 59, 2154-2156. [CrossRef]

39. Jiang, X.; Minnaard, A.J.; Hessen, B.; Feringa, B.L.; Duchateau, A.L.L.; Andrien, J.G.O.; Boogers, J.A.F.; de Vries, J.G. Application of monodentate secondary phosphine oxides, a new class of chiral ligands, in $\operatorname{Ir}(\mathrm{I})$-catalyzed asymmetric imine hydrogenation. Org. Lett. 2003, 5, 1503-1506. [CrossRef]

40. Gatineau, D.; Nguyen, D.H.; Hérault, D.; Vanthuyne, N.; Leclaire, J.; Giordano, L.; Buono, G. $\mathrm{H}$-adamantylphosphinates as universal precursors of P-stereogenic compounds. J. Org. Chem. 2015, 80, 4132-4141. [CrossRef]

41. Toda, F.; Mori, K.; Stein, Z.; Goldberg, I. Optical resolution of phosphinates and phosphine oxides by complex formation with optically active 2,2'-dihydroxy-1,1'-binaphthyl and crystallographic study of two diastereomeric complexes with methyl methylphenylphosphinate. J. Org. Chem. 1988, 53, 308-312. [CrossRef]

42. Drabowicz, J.; Łyżwa, P.; Omelańczuk, J.; Pietrusiewicz, K.M.; Mikołajczyk, M. New procedures for the resolution of chiral tert-butylphenylphosphine oxide and some of its reactions. Tetrahedron Asymmetry 1999, 10, 2757-2763. [CrossRef]

43. Holt, J.; Maj, A.M.; Schudde, E.P.; Pietrusiewicz, K.M.; Sieroń, L.; Wieczorek, W.; Jerphagnon, T.; Arends, I.W.C.E.; Hanefeld, U.; Minnaard, A.J. On the resolution of secondary phosphine oxides via diastereomeric complex formation: The case of tert-butylphenylphosphine oxide. Synthesis 2009, 2009, 2061-2065.

44. Bagi, P.; Ujj, V.; Czugler, M.; Fogassy, E.; Keglevich, G. Resolution of P-stereogenic P-heterocycles via the formation of diastereomeric molecular and coordination complexes (a review). Dalton Trans. 2016, 45, 1823-1842. [CrossRef] [PubMed]

45. Bagi, P.; Varga, B.; Szilágyi, A.; Karaghiosoff, K.; Czugler, M.; Fogassy, E.; Keglevich, G. The resolution of acyclic P-stereogenic phosphine oxides via the formation of diastereomeric complexes: A case study on ethyl-(2-methylphenyl)-phenylphosphine oxide. Chirality 2018, 30, 509-522. [CrossRef] [PubMed]

46. Dziuba, K.; Lubańska, M.; Pietrusiewicz, K.M. Enantiodivergent synthesis of both PAMPO enantiomers using 1-menthyl chloroacetate and stereomutation at $\mathrm{P}$ in classical quaternisation reactions. Synthesis 2019. Available online: https://www.thieme-connect.com/products/ejournals/abstract/10.1055/s-0039-1691531 (accessed on 14 January 2020). [CrossRef]

47. Faigl, F.; Fogassy, E.; Nógrádi, M.; Pálovics, E.; Schindler, J. Strategies in optical resolution: A practical guide. Tetrahedron Asymmetry 2008, 19, 519-536. [CrossRef]

48. Mane, S. Racemic drug resolution: A comprehensive guide. Anal. Methods 2016, 8, 7567-7586. [CrossRef]

49. Bagi, P.; Herbay, R. Resolution of phosphine oxides. In Organophosphorus Chemistry—Novel Developments; Keglevich, G., Ed.; De Gruyter: Berlin, Germany, 2018; pp. 66-90.

50. Meisenheimer, J.; Casper, J.; Höring, M.; Lauter, W.; Lichtenstadt, L.; Samuel, W. Optisch-aktive Phosphinoxyde. J. Liebig. Ann. Chem. 1926, 449, 213-248. [CrossRef]

51. Kozma, D.; Bocskei, Z.; Kassai, C.; Simon, K.; Fogassy, E. Optical resolution of racemic alcohols by diastereoisomeric complex formation with $O, O^{\prime}$-dibenzoyl- $(2 R, 3 R)$-tartaric acid; the crystal structure of the (-)-(1R,2S,5R)-menthol-O,O'-dibenzoyl-(2R,3R)-tartaric acid complex. Chem. Commun. 1996, 635, 753-754. [CrossRef]

52. Mravik, A.; Böcskei, Z.; Katona, Z.; Markovits, I.; Fogassy, E. Coordination-mediated optical resolution of carboxylic acids with $O, O^{\prime}$-dibenzoyltartaric acid. Angew. Chem. Int. Ed. 1997, 36, 1534-1536. [CrossRef]

53. Xu, H.; Wang, Q.; Zhu, J.; Deng, J.; Cun, L.; Cui, X.; Wu, J.; Xu, X.; Wu, Y. Copper(II)-mediated resolution of alpha-halo carboxylic acids with chiral $O, O^{\prime}$-dibenzoyltartaric acid: Spontaneous racemization and crystallization-induced dynamic resolution. Org. Biomol. Chem. 2005, 3, 4227-4232. [CrossRef]

54. Degenbeck, H.; Felten, A.S.; Etxebarria, J.; Escudero-Adán, E.C.; Benet-Buchholz, J.; Vidal-Ferran, A. Crystallization-induced dynamic resolution of stereolabile biaryl derivatives involving supramolecular interactions. Cryst. Growth Des. 2012, 12, 2719-2723. [CrossRef]

55. Hu, Y.; Wu, C.; Wu, X.Y.; Li, S.L.; Sun, X.X.; Tang, Z.B. Efficient preparation of (R)-2-chloromandelic acid via a recycle process of resolution. Chirality 2015, 27, 281-285. [CrossRef] 
56. Yang, B.; Xie, H.; Ran, K.; Gan, Y. Efficient synthesis and resolution of Tenofovir Alafenamide. Lett. Org. Chem. 2017, 15, 10-14. [CrossRef]

57. Ujj, V.; Schindler, J.; Novák, T.; Czugler, M.; Fogassy, E.; Keglevich, G. Coordinative resolution of 1-phenyland 1-naphthyl-3-methyl-3-phospholene 1-oxides with calcium hydrogen $O, O^{\prime}$-dibenzoyl-(2R,3R)-tartrate or calcium hydrogen $O, O^{\prime}$-di-p-toluyl-(2R,3R)-tartrate. Tetrahedron Asymmetry 2008, 19, 1973-1977. [CrossRef]

58. Bagi, P.; Karaghiosoff, K.; Czugler, M.; Hessz, D.; Kállay, M.; Kubinyi, M.; Szilvási, T.; Pongrácz, P.; Kollár, L.; Timári, I.; et al. Synthesis, characterization, and application of platinum(II) complexes incorporating racemic and optically active 4-chloro-5-methyl-1-phenyl-1,2,3,6-tetrahydrophosphinine ligand. Heteroatom. Chem. 2016, 27, 91-101. [CrossRef]

59. Faigl, F.; Fogassy, E.; Nógrádi, M.; Pálovics, E.; Schindler, J. Separation of non-racemic mixtures of enantiomers: An essential part of optical resolution. Org. Biomol. Chem. 2010, 8, 947-959. [CrossRef]

(C) 2020 by the authors. Licensee MDPI, Basel, Switzerland. This article is an open access article distributed under the terms and conditions of the Creative Commons Attribution (CC BY) license (http://creativecommons.org/licenses/by/4.0/). 